\title{
PERAN MUTU DALAM MENUNJANG EKSPOR UDANG NASIONAL
}

\author{
Sumpeno Putro*)
}

\begin{abstract}
ABSTRAK
Udang merupakan komoditi andalan ekspor dari sektor perikanan Indonesia. Akan tetapi, volume ekspor udang Indonesia dalam beberapa tahun terakhir ini cenderung menurun. Hal ini terutama disebabkan karena semakin ketatnya persyaratan impor yang diberlakukan oleh negaranegara maju, khususnya standar mutu dan sanitasi. Ekspor udang ke Uni Eropa merosot dan dikenakan RAS (Rapid Alert System) karena dicurigai mengandung residu antibiotik dan bakteri patogen. Ekspor udang ke Amerika Serikat, juga masih dikenakan automatic detention. Sementara itu, pada tahun 2006 dan 2007 ekspor udang ke Jepang dan Cina juga ditolak karena dicurigai mengandung residu antibiotik. Oleh karena itu, pengembangan sistem pembinaan mutu dan sertifikasi secara terpadu dengan konsep from farm to table sangat diperlukan untuk meningkatkan daya saing dan akses pasar dalam menghadapi era globalisasi. Dalam kaitan ini, pengembangan industri udang budidaya ke depan sebaiknya tidak hanya berorientasi kepada upaya peningkatan produksi, tetapi juga memperhatikan aspek mutu dan keamanan pangan (food safety) agar produk yang dihasilkan layak dan aman untuk dikonsumsi serta memenuhi standar mutu yang berlaku di pasar internasional.
\end{abstract}

KATA KUNCI: mutu, udang, ekspor

\section{PENDAHULUAN}

Dalam era globalisasi, tuntutan konsumen terhadap standar mutu dan keamanan pangan produk perikanan semakin meningkat. Oleh karena itu, walaupun permintaan dunia terhadap impor produk perikanan terus meningkat, jalan ke depan cukup sulit dan berliku. Tuntutan ini seiring dengan arah globalisasi perdagangan, yang terus mengedepankan pentingnya aspek mutu dan keamanan pangan, sehingga perbaikan sistem pembinaan mutu sangat diperlukan untuk meningkatkan daya saing dan akses pasar (Putro, 2006; 2007a,b). Hal ini disebabkan karena produk perikanan merupakan bahan pangan yang sangat mudah busuk, sehingga menuntut cara penanganan dan pengolahan yang cepat dan tepat agar mutu dan kesegarannya tetap prima. Hasil penelitian menunjukkan bahwa cara penanganan yang kurang baik, telah mengakibatkan terjadinya kontaminasi oleh bakteri penyakit dan kerusakan pascapanen sekitar 25-30\%. Hasil penelitian juga menunjukkan bahwa udang windu ( $P$. monodon) yang baru saja dipanen dari tambak ternyata telah terkontaminasi oleh E. coli, Salmonella, dan Vibrio parahaemolyticus (Putro, 2007c). Masalah ini sering menjadi faktor penghambat dalam usaha industri udang nasional dan diperkirakan menjadi penyebab utama terjadinya kasus penahanan dan penolakan terhadap ekspor udang Indonesia di luar negeri (Putro, 2003).
Di samping itu, dengan semakin meningkatnya kekhawatiran masyarakat terhadap aspek mutu dan keamanan pangan dari produk perikanan yang diperdagangkan di pasar internasional akhir-akhir ini, beberapa negara maju mulai menerapkan persyaratan mutu yang lebih ketat terhadap udang yang diimpor dari negara-negara berkembang (Putro, 2007c). Bahkan beberapa negara maju seperti Uni Eropa (UE), mulai memberlakukan sistem traceability secara wajib (mandatory) bagi produk perikanan termasuk udang. Hal ini dimaksudkan untuk memulihkan kembali kepercayaan konsumen terhadap jaminan mutu dan keamanan pangan bagi produk perikanan, yang dalam beberapa tahun terakhir ini merosot dari $83 \%$ menjadi 64\% (Putro, 2007c). Penerapan standar mutu dan sanitasi yang lebih ketat inilah yang mengakibatkan merosotnya volume ekspor udang dari Indonesia.

Dampak negatif yang paling menonjol adalah menurunnya ekspor hasil perikanan ke Uni Eropa, khususnya udang. Nilai ekspor produk perikanan Indonesia merosot dari sekitar 0,7 tahun 2001 menjadi 0,3 milyar dollar pada tahun 2006 . Volume ekspor udang Indonesia, merosot sekitar $64 \%$ sejak diberlakukannya zero tolerance terhadap residu kloramfenikol dan nitrofuran pada pertengahan tahun 2001. Puluhan kontainer udang ditahan dan dimusnahkan di pelabuhan masuk di UE sehingga menimbulkan kerugian ekonomi yang sangat besar serta mengakibatkan terjadinya kegalauan bagi industri udang nasional (Putro, 2006).

\footnotetext{
*) Peneliti pada Balai Besar Riset Pengolahan Produk dan Bioteknologi Kelautan dan Perikanan
} 


\section{PERKEMBANGAN EKSPOR UDANG}

Udang merupakan komoditi andalan ekspor produk perikanan Indonesia di samping ikan tuna. Saat ini udang menyumbang lebih dari $62 \%$ dari total nilai ekspor produk perikanan Indonesia. Pasar utama ekspor udang Indonesia adalah Jepang (52\%), Amerika Serikat (18\%), dan Eropa (15\%) (Putro, 2004). Perkembangan ekspor udang dalam beberapa tahun terakhir ini dapat dilihat pada Tabel 1 dan 2.
60.235 ton pada tahun 2003 , tetapi terus menurun menjadi 48.623 ton pada tahun 2004 dan 46.051 ton pada tahun 2005. Penurunan volume ekspor udang ini nampaknya merupakan dampak dari pengetatan terhadap standar mutu khususnya residu antibiotik pada udang impor oleh pemerintah Jepang. Sejak tahun 2004, pemerintah Jepang mengikuti jejak Uni Eropa dengan menerapkan zero tolerance terhadap residu kloramfenikol dan nitrofuran pada udang impor. Akibatnya, beberapa kontainer udang yang diekspor

Tabel 1. Perkembangan volume ekspor udang tahun 2000-2006 (dalam ton)

\begin{tabular}{lccccccc}
\hline Negara tujuan & 2000 & 2001 & 2002 & 2003 & 2004 & 2005 & 2006 \\
\hline Jepang & 54.064 & 59.559 & 59.618 & 60.235 & 48.623 & 46.051 & 50.581 \\
USA & 16.216 & 16.153 & 16.837 & 21.901 & 46.966 & 50.698 & 61.235 \\
Uni Eropa & 17.833 & 20.056 & 16.140 & 23.689 & 26.317 & 27.179 & 35.232 \\
\hline
\end{tabular}

Sumber: Anon., 2007

Tabel 2. Perkembangan nilai ekspor udang tahun 2000-2006 (dalam US\$ 000)

\begin{tabular}{lccccccc}
\hline Negara tujuan & 2000 & 2001 & 2002 & 2003 & 2004 & 2005 & 2006 \\
\hline Jepang & 612.460 & 564.998 & 506.585 & 473.953 & 391.140 & 373.534 & 420.252 \\
USA & 170.187 & 144.295 & 137.082 & 156.910 & 279.385 & 327.819 & 418.556 \\
Uni Eropa & 120.818 & 122.509 & 121.871 & 127.417 & 132.745 & 159.292 & 196.430 \\
\hline
\end{tabular}

Sumber: Anon., 2007

Sebagian besar udang diekspor dalam bentuk beku (IQF dan block) baik dalam bentuk headless shell-on (HSO) atau peeled and de-veined (P \& D). Akan tetapi, ekspor produk-produk bernilai tambah seperti breaded shrimp, butterfly, dan tempura juga semakin meningkat seiring dengan meningkatnya permintaan produk perikanan siap saji di pasar internasional (Putro, 2004).

Dalam beberapa tahun terakhir ini, nilai ekspor udang di pasar dunia cenderung mengalami penurunan. Hal ini terutama disebabkan oleh melemahnya harga rata-rata udang di pasar internasional sebagai akibat dari lonjakan produksi, terutama udang vannamae. Di samping itu, akhir-akhir ini banyak muncul berbagai hambatan perdagangan seperti isu dumping, isu lingkungan, serta persyaratan mutu yang dikemas dalam berbagai macam aturan seperti zero tolerance terhadap residu antibiotik, Bioterrorism Act, dan Traceability.

Volume ekspor udang Indonesia ke Jepang meningkat dari 54.064 ton pada tahun 2000 menjadi dari Indonesia, ditahan atau ditolak di pelabuhan masuk karena dicurigai mengandung antibiotik tersebut. Seperti diketahui bahwa pemeriksaan terhadap residu antibiotik di Jepang selama ini hanya difokuskan pada tetrasiklin termasuk OTC (oxytetracycline) dan CTC (chlor tetracycline). Bahkan terdapat indikasi bahwa Jepang juga akan mengikuti jejak Uni Eropa dan AS dalam menerapkan sistem traceability (Putro, 2006; 2007b).

Diperkirakan Jepang masih tetap akan merupakan pasar yang prospektif bagi udang Indonesia mengingat udang impor menyumbang sekitar $80 \%$ dari kebutuhan domestik di Jepang. Walaupun demikian, persaingan yang semakin ketat perlu diwaspadai terutama dengan melonjaknya pasokan dari Vietnam, Cina, dan Myanmar yang harganya lebih murah dan sangat kompetitif. Sementara itu, masih lesunya kondisi perekonomian Jepang menyebabkan konsumen beralih dari snob consumers menjadi smart consumers, dan harga menjadi faktor penentu utama. Meskipun masyarakat Jepang mempunyai 
kesadaran yang tinggi terhadap mutu dan menjadikan faktor kesegaran di atas segala-galanya, tetapi saat ini masalah harga menjadi pertimbangan utama. Untuk mengantisipasi hal ini, peningkatan mutu dan efisiensi produksi perlu untuk mendapatkan perhatian dari semua stakeholders.

Di lain pihak, konsumsi udang di Amerika Serikat (AS) meningkat hampir $143 \%$ selama 20 tahun terakhir ini. Total permintaan yang sedemikian besar ini menjadikan AS sebagai pasar udang terbesar di dunia. Volume ekspor udang dari Indonesia ke AS dari tahun 2000 sampai 2002 tidak menunjukkan kenaikan, yaitu sekitar 16.500 ton. Kemudian meningkat menjadi 21.901 pada tahun 2003 dan 61.235 ton pada tahun 2006. Hal ini menunjukkan bahwa kenaikan ekspor udang Indonesia ke Amerika Serikat tidak terlalu menonjol walaupun telah terbebas dari petisi anti dumping pada awal tahun 2002. Bahkan pangsa pasar udang Indonesia justru merosot tajam dari $13,4 \%$ pada Januari-April 2007 menjadi 10,2\% dibanding periode yang sama tahun 2006. Hal ini disebabkan karena semakin ketatnya persyaratan impor udang ke AS, antara lain diberlakukannya Bioterrorism Act, COOL (Country of Origin Labeling), dan pencabutan green card apabila mutu udang ekspor tidak memenuhi standar. Selain isu di atas, pada awal tahun 2003 pemerintah AS juga memberlakukan ketentuan Public Health Security and Bioterrorism Preparedness and Response Act (Bioterrorism Act-PL 107-188). Dari ketentuan tersebut, kelompok industri makanan yang membuat, memproses, mengemas, dan menyimpan bahan makanan yang akan diekspor ke AS diwajibkan untuk mendaftarkan perusahaannya kepada US-Food and Drugs Administration (Putro, 2007b).

Uni Eropa merupakan pasar udang terbesar ketiga setelah Amerika Serikat dan Jepang. Pasar Uni Eropa sangat bergantung kepada pasokan dari mancanegara, dan sekitar $70 \%$ dari total kebutuhan udang berasal dari impor. Pemasok udang terbesar ke UE adalah Argentina, Cina, India, Indonesia, Bangladesh, Thailand, Ekuador, Malaysia, Brazil, Madagaskar, dan Vietnam. Ekspor udang Indonesia ke Uni Eropa tahun 2000 mencapai 17.833 ton, kemudian naik menjadi 20.056 ton pada tahun 2001. Tetapi sejak diterapkan zero tolerance terhadap residu antibiotik kloramfenikol dan nitrofuran oleh Komisi Eropa diikuti dengan pengetatan pemberlakukan RAS (Rapid Alert System) pada akhir tahun 2001, ekspor udang ke Uni Eropa pada tahun 2002 merosot menjadi 16.140 ton. Untuk mengatasi masalah ini, pemerintah bersama seluruh stakeholders yang bergerak di bidang industri udang berusaha keras untuk memperbaiki sistem pembinaan mutu terpadu mulai dari pabrik pakan, hatchery, pertambakan, sampai industri pengolahan sejak awal tahun 2003. Di samping itu, pemeriksaan terhadap persyaratan mutu terus diperketat, dan hanya udang yang mutunya bagus serta bebas dari residu antibiotik yang diizinkan untuk diekspor. Langkah ini memberikan hasil yang cukup menggembirakan. Hal ini terlihat dari data yang menunjukkan peningkatan volume ekspor udang Indonesia ke Uni Eropa dari 23.689 ton pada tahun 2003 menjadi 35.232 ton pada tahun 2006 (Putro, 2007c).

Uni Eropa memberlakukan persyaratan mutu yang lebih ketat terhadap impor produk perikanan budidaya. Sesuai dengan EC Food Law No. EC/2002/178 dan EU Regulation No. 2377/90 tentang Regulation on Residue Control and Monitoring of Aquaculture Products, maka semua negara eksportir produk perikanan budidaya diwajibkan untuk menyampaikan laporan hasil monitoring residu obat-obatan dan antibiotik kepada Directorate General of Health and Consumer Protection (DG Sanco) secara rutin setiap tahun. Kelalaian terhadap kewajiban ini dapat mengakibatkan dikenakannya export suspension atau embargo terhadap semua produk perikanan budidaya. Saat ini Komisi Eropa mengeluarkan peraturan baru yang mengharuskan semua bahan pangan impor termasuk udang dikenakan uji kandungan residu antibiotik di setiap pelabuhan masuk. Bahkan Uni Eropa juga memberlakukan zero tolerance terhadap residu antibiotik furazolidon (Putro, 2006).

Di lain pihak, nampaknya Jepang akan terus memberlakukan sistem traceability dan pengetatan terhadap penggunaan antibiotik, di samping standar mikrobiologi khususnya untuk komoditi udang siap saji seperti terlihat pada Tabel 3.

Situasi pasar udang diperburuk lagi dengan munculnya larangan pemerintah Cina terhadap impor udang dari Indonesia pada awal tahun 2007. Larangan impor tersebut disebabkan karena udang Indonesia disinyalir mengandung residu obat-obatan terlarang khususnya kloramfenikol dan nitrofuran (Anon., 2007). Kasus ini memperkeruh reputasi mutu udang ekspor Indonesia, mengingat bahwa Cina merupakan pengimpor hasil perikanan Indonesia terbesar kedua di Asia setelah Jepang.

\section{LANGKAH TINDAK LANJUT}

Diharapkan udang akan tetap menjadi primadona ekspor hasil perikanan dalam dasawarsa ke depan karena komoditas ini termasuk jenis yang paling banyak diminati oleh para konsumen di berbagai penjuru dunia. Indonesia sebagai negara kepulauan mempunyai potensi yang sangat besar dalam pengembangan industri udang nasional baik untuk tujuan ekspor maupun untuk memenuhi kebutuhan 
Tabel 3. Peraturan mengenai residu antibiotik pada produk perikanan impor ke Jepang

\begin{tabular}{|c|c|c|c|}
\hline Negara asal & Jenis produk & Antibiotik yang dipersyaratkan & Jenis pemeriksaan \\
\hline Indonesia & $\begin{array}{l}\text { Udang budidaya beku } \\
\text { termasuk produk } \\
\text { olahan bernilai tambah }\end{array}$ & $\begin{array}{l}\text { Tetracycline, oxytetracycline, } \\
\text { chlortetracycline, kloramfenikol, } \\
\text { dan nitrofuran }\end{array}$ & $\begin{array}{l}\text { Semua kargo harus } \\
\text { diperiksa }\end{array}$ \\
\hline Filipina & $\begin{array}{l}\text { Udang budidaya beku } \\
\text { termasuk produk } \\
\text { olahan bernilai tambah }\end{array}$ & Semua antibiotik & $\begin{array}{l}\text { Semua kargo harus } \\
\text { diperiksa }\end{array}$ \\
\hline Thailand & $\begin{array}{l}\text { Udang budidaya beku } \\
\text { termasuk produk } \\
\text { olahan bernilai tambah }\end{array}$ & $\begin{array}{l}\text { Semua antibiotik, } \\
\text { asam oxolonat }\end{array}$ & $\begin{array}{l}\text { Semua kargo harus } \\
\text { diperiksa kecuali } \\
\text { produk dari } \\
\text { perusahaan yang } \\
\text { sudah approved }\end{array}$ \\
\hline $\begin{array}{l}\text { Bangladesh, India, } \\
\text { dan Myanmar }\end{array}$ & Udang budidaya beku & $\begin{array}{l}\text { Kloramfenikol, asam oxolonat, } \\
\text { sulfamerazine, sulfadimidine }\end{array}$ & $\begin{array}{l}10 \% \text { dari kargo yang } \\
\text { diimpor }\end{array}$ \\
\hline Vietnam & $\begin{array}{l}\text { Udang budidaya beku } \\
\text { termasuk produk } \\
\text { olahan bernilai tambah }\end{array}$ & $\begin{array}{l}\text { Sulfamono-methoxine, } \\
\text { sulfadimethoxine, } \\
\text { sulfaquinoxaline }\end{array}$ & $\begin{array}{l}\text { Semua kargo harus } \\
\text { diperiksa }\end{array}$ \\
\hline China & $\begin{array}{l}\text { Udang budidaya beku } \\
\text { termasuk produk } \\
\text { olahan bernilai tambah }\end{array}$ & $\begin{array}{l}\text { Semua antibiotik, asam oxolonat, } \\
\text { sulfamerazine, sulfadimedine, } \\
\text { sulfamono-methoxine, } \\
\text { sulfadimethoxine, } \\
\text { sulfaquinoxaline, dan } 2 \text { antibiotik } \\
\text { quinolone baru }\end{array}$ & $\begin{array}{l}\text { Semua kargo harus } \\
\text { diperiksa }\end{array}$ \\
\hline
\end{tabular}

Sumber: Tookwinas \& Keerativiriyaporn, (2004); Putro, (2007b)

gizi nasional. Walaupun permintaan dunia terhadap impor produk perikanan terus meningkat dan potensi pengembangan ekspor sangat prospektif, jalan ke depan cukup sulit dan berliku (Anon., 2007). Hal ini disebabkan karena pengembangan ekspor hasil perikanan dalam era globalisasi akan dihadapkan pada persyaratan mutu dan persaingan yang semakin ketat. Bahkan reputasi mutu produk perikanan Indonesia di pasar internasional saat ini sedang dipertaruhkan. Pada tanggal 3-14 September 2007, tim inspeksi dari US-FDA (Food and Drugs Administration) telah datang ke Indonesia untuk melakukan verifikasi terhadap sistem jaminan mutu produk perikanan khususnya udang, lalu disusul tim FVO-Uni Eropa (Food and Veterinary Office) pada tanggal 21-30 November 2007. Hasil inspeksi tim US-FDA dan UE ini menjadi titik kritis bagi kelanjutan industri perikanan Indonesia di percaturan perdagangan dunia. Hal ini seiring dengan arah globalisasi perdagangan yang mengedepankan pentingnya penanganan terhadap aspek mutu dan keamanan pangan (Anon., 2007). Oleh karena itu, peningkatan sistem pembinaan mutu menjadi faktor penentu dalam menghadapi era globalisasi perdagangan (Putro, 2006).

Kebijakan Uni Eropa dalam menerapkan zero tolerance terhadap residu antibiotik pada udang nampaknya akan berimbas kepada negara-negara maju lain khususnya Jepang dan Amerika Serikat dalam memperketat pengawasan dan pemberlakuan standar residu antibiotik. Oleh karena itu, pemerintah dan semua stakeholders terkait harus secara serius memperbaiki sistem jaminan mutu dan sertifikasi dengan konsep from farm/catch to table. Penerapan self-regulatory yang terukur dan sanksi berat bagi perusahaan yang melanggar ketentuan akan dinilai sebagai upaya serius oleh pihak Komisi Eropa. Kerjasama yang erat antara pemerintah dengan asosiasi perlu terus digalakkan, mengingat akses pasar dan mutu udang Indonesia di pasar Eropa saat ini terpuruk. Di samping itu, peningkatan citra mutu produk Indonesia perlu secara terus menerus digaungkan dan dilaksanakan oleh semua pihak 
terkait. Hal ini mengingat bahwa persyaratan mutu dan sanitasi akan banyak dipakai sebagai hambatan non tarif oleh negara-negara maju.

Salah satu langkah penting yang perlu diadopsi oleh industri udang nasional adalah diterapkannya sistem HACCP (Hazard Analysis Critical Control Point) dalam budidaya dan pengolahan produk-produk perikanan khususnya udang. Hal ini mengingat bahwa pengembangan budidaya udang intensif seringkali hanya mengutamakan peningkatan produksi dan menyampingkan aspek mutu dan keamanan pangan, padahal produk udang budidaya sangat rentan terhadap kontaminasi bakteri-bakteri patogen seperti Salmonella dan V. cholera maupun residu antibiotik/ obat-obatan dan pestisida yang dapat membahayakan kesehatan konsumen (Putro, 2007b) seperti terlihat pada Tabel 4. Oleh karena itu, dimasukkannya konsep HACCP dalam standar budidaya udang adalah sebagai langkah preventif untuk mencegah residu obat-obatan dan kontaminasi berbagai senyawa kimia dalam produk udang budidaya, serta untuk mencegah terjadinya kontaminasi mikrobiologi baik selama udang dibudidayakan di kolam/tambak maupun di unit pengolahan (Putro, 2007b; Sumner et al., 2004).

Beberapa langkah pengendalian terhadap titik-titik rawan (critical points) yang perlu dicermati dalam budidaya udang antara lain:

a. Pengendalian di tingkat petambak/pembudidaya

Pengendalian di tingkat petambak/pembudidaya udang meliputi pendaftaran kolam/tambak (Farm registration), pengendalian penggunaan pakan/ antibiotik, monitoring residu obat/antibiotik pada udang hasil budidaya, monitoring mutu air yang masuk dan keluar (inlet dan outlet), inspeksi terhadap farm hygiene, dan penanganan pascapanen.

\section{b. Farm registration}

Semua kolam dan tambak udang harus terdaftar dan mempunyai izin pengoperasioan dari pihak yang berwenang (Competent authority). Persyaratan pokok yang harus dipenuhi antara lain tersedianya water treatment ponds dan rancangan tata letak kolam yang disetujui pejabat berwenang (Ditjen Perikanan Budidaya).

\section{c. Farm inspection}

Farm inspection diperlukan untuk meyakinkan bahwa setiap farm benar-benar menerapkan standar operasi dan sanitasi sesuai dengan Codex guidelines. Contohnya yaitu untuk usaha budidaya yang lebih dari 8 ha diwajibkan untuk mempunyai program manajemen usaha budidaya yang disyahkan oleh instansi berwenang dan diinspeksi 2 sampai 4 kali/ tahun.

\section{d. Feed quality control}

Untuk mencegah penggunaan pakan yang mengandung antibiotik, baik sengaja maupun tidak, maka diperlukan langkah-langkah preventif termasuk pendaftaran formula pakan, sampling, dan analisa kandungan antibiotik pada pakan serta inspeksi dan sertifikasi terhadap semua pabrik pakan.

\section{e. Farm monitoring}

Langkah ini sangat diperlukan untuk memantau kesesuaian manajemen usaha budidaya dengan peraturan yang berlaku dan menentukan peringkat

Tabel 4. Beberapa Hazard yang terkait dengan budidaya udang

\begin{tabular}{|c|c|c|}
\hline Kategori & Contoh Hazard & \\
\hline Hazard biologis & Bakteri patogen & $\begin{array}{l}\text { Salmonella, Shigella, E. coli, V. cholera, } \\
\text { V. parahaemolyticus, V. vulnificus, } \\
\text { Listeria monocytogenes, dan lain-lain }\end{array}$ \\
\hline \multirow[t]{2}{*}{ Hazard kimiawi } & Residu obat-obatan & $\begin{array}{l}\text { Hormon, pengatur tumbuh, antibiotik } \\
\text { seperti kloramfenikol, nitrofuran, dan } \\
\text { metabolitnya serta antibiotik yang tidak } \\
\text { dilarang dan residunya tidak melebihi } \\
\text { MRL (Maximum Residue Limit) }\end{array}$ \\
\hline & Residu pestisida & $\begin{array}{l}\text { Herbisida, fungisida, insektisida, dan lain- } \\
\text { lain }\end{array}$ \\
\hline Hazard fisika & $\begin{array}{l}\text { Pecahan kaca, kayu, } \\
\text { logam, dan sebagainya }\end{array}$ & \\
\hline
\end{tabular}

Sumber: Tookwinas \& Keerativiriyaporn, (2004); Putro, (2007b) 
sanitasi dari setiap usaha budidaya (Farm sanitation rating) sesuai dengan Codex Code of Good Hygienic Practices untuk produk perikanan budidaya.

\section{f. Raw materials control}

Effektivitas dari penerapan sistem HACCP di farm level akan tercermin dari kandungan residu obatobatan/antibiotik pada bahan baku yang dihasilkan. Untuk melihat efektivitas penerapan sistem HACCP ini diperlukan farm record dan hasil sampling terhadap udang yang dibudidayakan 3 bulan sebelum dipanen, terutama untuk melihat residu obat-obatan/antibiotik dalam daging udang tersebut. Bagi udang hasil budidaya yang tidak mengandung obat-obatan harus diberikan sertifikat bebas antibiotik. Langkah ini sangat diperlukan untuk menjamin bahwa semua bahan baku yang masuk ke unit pengolah benar-benar bebas dari obat-obatan/antibiotik sekaligus untuk memfasilitasi penerapan sistem traceability dalam sistem budidaya udang yang baik.

\section{g. Unit pengolah}

Untuk memastikan bahwa produk akhir yang dihasilkan dari setiap unit pengolah benar-benar bebas dari residu obat-obatan/antibiotik terlarang, memenuhi standar mutu dan higienis yang dipersyaratkan, maka diperlukan monitoring terhadap penerapan sistem pembinaan mutu di semua unit pengolah. Program monitoring tersebut mencakup:

(1) penerapan sistem sanitasi, higienis dan GMP (Good Manufacturing Practices) sebagai landasan pokok dari program pembinaan mutu,

(2) penerapan sistem pembinaan mutu yang mengacu kepada sistem HACCP dan/atau ISO-22000,

(3) sistem pembinaan mutu yang diterapkan oleh setiap unit pengolah harus diverifikasi oleh Competent Authority.

Bagi unit-unit pengolah yang telah menerapkan sistem pembinaan mutu yang baik diberikan Approval Number dan dimasukkan dalam List of Approved Fish Processing Plants. Sebagai prasyarat dan kelengkapan dokumen ekspor, maka setiap pengapalan harus dilengkapi dengan Health Certificate dan Certificate of Analysis yang menyatakan bahwa produk tersebut layak dan aman untuk konsumsi (Putro, 2007b).

\section{PENUTUP}

Dari uraian diatas terlihat bahwa peluang pengembangan ekspor udang sangat cerah, namun jalan ke depan sangat sulit dan berliku. Hal ini terutama disebabkan karena persyaratan mutu dan sanitasi yang diberlakukan oleh negara-negara maju semakin ketat. Persyaratan mutu ini sering dikemas dalam suatu aturan yang nampak elegan, tetapi sebenarnya merupakan hambatan terselubung dalam perdagangan. Oleh karena itu, diperlukan program pembinaan mutu dan sertifikasi yang komprehensif dan visioner mulai dari hulu sampai hilir. Pengembangan sistem jaminan mutu yang terakreditasi dan terukur serta kebijakan pengembangan pengolahan dan pemasaran, perlu dirumuskan dalam satu paket kebijakan yang terintegrasi. Paket kebijakan ini harus mendapat dukungan dari semua instansi terkait sehingga mempunyai bobot politis yang tinggi. Diharapkan, dengan potensi tambak sekitar 1 juta ha, sudah sepantasnya apabila Indonesia menjadi produsen dan eksportir udang nomor satu dunia dalam beberapa tahun mendatang ini.

\section{DAFTAR PUSTAKA}

Anonim. 2007. Perkembangan pasar udang Asia. Warta Pasar Ikan, Edisi April 2007. Direktorat Jenderal Pengolahan dan Pemasaran Hasil Laut dan Ikan. Departemen Kelautan dan Perikanan.

Putro, S. 2003. Penahanan dan Penolakan Ekspor Hasil Perikanan di Uni Eropa dalam "Perikanan sebagai sektor andalan nasional”. Cholik, F., Heruwati, E.S., Jauzi, A. dan Basuki, P.I. (eds.). ISPIKANI dan Departemen Kelautan dan Perikanan. Jakarta.

Putro, S. 2004. Indonesian Shrimp Industry Outlook2004 and Beyond. Global Shrimp Outlook Conference. Los Cabos, Mexico.

Putro, S. 2006. Industri Perikanan dalam Era Globalisasi. Makalah disajikan dalam Seminar Nasional dan Diseminasi Pengembangan Hasil Perikanan. Bandar Lampung.

Putro, S. 2007a. Implikasi Pasar Global dan Codex terhadap Industri Perikanan Budidaya. Makalah disajikan dalam Acara Temu Pakar. Direktorat Jenderal Perikanan Budidaya. Yogyakarta.

Putro, S. 2007b. Kiat Mendorong Ekspor Udang. Majalah TROBOS.

Putro, S. 2007c. Dampak Globalisasi Perdagangan terhadap Ekspor Hasil Perikanan Indonesia. Orasi Pengukuhan Profesor Riset. LIPI. Departemen Kelautan dan Perikanan.

Sumner, J., Ross, T. and Ababouch, L. 2004. Application of Risk Assessment in the Fish Industry. FAO Fisheries Technical Paper. 442, Rome, Italy.

Tookwinas, S. and Keerativiriyaporn, S. 2004. HACCP in shrimp farming. Aquaculture Asia, IX (2). 